\title{
PENGARUH RESPON DAN KEIKUTSERTAAN WAJIB PAJAK DALAM PROGRAM TAX AMNESTY TERHADAP KEPATUHAN WAJIB PAJAK DI BEKASI
}

\author{
Tutty Nuryati ${ }^{1}$, Muhammad Hasbi Saleh ${ }^{2}$ \\ Sekolah Tinggi Ilmu Ekonomi Indonesia \\ Jl. Kayu Jati Raya No. 11, Rawamangun, Jakarta \\ tutty_siregar@ymail.com, hasbisaleh@gmail.com
}

\begin{abstract}
This study aims to determine the effect of taxpayer response and participation in the tax amnesty program on Taxpayer compliance, both formal compliance and material compliance. The hypothesis is the response and taxpayer participation in the tax amnesty program affect the formal compliance and taxpayer material. This research is located in Bekasi with taxpayer analysis unit registered in KPP Pratama Bekasi Utara, Bekasi Selatan, CikarangUtara, Cikarang Selatan, and Cibitung. Data collection techniques were conducted with questionnaires and interviews and literature study. Data analysis using Structural Equation Modelling (SEM). The result of the research found: 1) there is a positive correlation between Taxpayer response to tax amnesty program to Taxpayer participation in Tax amnesty program 2) there is a positive relationship between Taxpayer response to tax amnesty program to formal Compliance 3) there is no positive relationship between the obligatory participation Tax on the tax amnesty program on formal compliance 4) there is a positive relationship between taxpayers' response to the tax amnesty program on material compliance 5) there is no positive correlation between formal compliance of Taxpayer to material compliance 6) there is no positive relationship between taxpayer participation to compliance material.
\end{abstract}

Keywords : Response, participation, tax amnesty, tax compliance, taxpayer

\section{PENDAHULUAN}

Penerimaan pajak merupakan komponen utama penerimaan dalam negeri, dimana untuk meningkatkan jumlah penerimaan, pemerintah mulai dengan melakukan reformasi perpajakan secara menyeluruh pada tahun 1983 dan sejak itulah Indonesia menganut self assessment system. Dari data yang ada, tidak kurang dari $75 \%$ anggaran pendapatan dan Penerimaan pajak merupakan komponen utama penerimaan negara, dimana berdasarkan target APBN tahun 2016 komponen pajak ditargetkan menyumbang 1.360,2 trilyun atau sekitar $75 \%$ dari total target APBN. Ini merupakan tugas besar dari Ditjen pajak untuk dapat memenuhi target tersebut.

Sebagai sebuah kebijakan yang lebih memandang ke dalam (inward looking policy), penerimaan dari sektor pajak diharapkan mampu mengurangi ketergantungan pada utang luar negeri serta mampu membangkitkan kembali kepercayaan diri bangsa Indonesia. Ini selaras dengan misi yang diemban oleh Direktorat Jenderal Pajak selaku otoritas pajak yang berkompeten di negeri ini, yaitu menghimpun penerimaan negara dari sektor pajak guna menunjang kemandirian pembiayaan APBN (Iswahyudi, 2005).

Namun demikian bukan hal yang mudah bagi pemerintah untuk dapat mengumpulkan dana yang diperlukan tersebut. Dana yang berasal dari dalam negeri tidak mencukupi untuk semua pembiayaan proyek yang sudah direncanakan. Apakah memang harus mencari dana dari luar dalam bentuk hutang kepada Negara lain? Kalau iya bagaimana dengan beban bunga yang harus dibayar? 
Apakah tidak ada lagi dana yang biasa kita tarik dari investor dalam negeri sehingga jumlah yang harus kita pinjam dari luar negeri sebegitu besarnya? Pertanyaan-pertanyaan inilah yang menjadi alasan pemerintah untuk melakukan upaya persuasif, berupa himbauan kepada para investor untuk memberikan partisipasinya terhadap pembangunan Negara.

Sudah menjadi rahasia umum bahwa banyak investor kita yang notabene merupakan Wajib Pajak yang menanamkan investasinya di luar sehingga jumlahnya tidak diketahui negara dan pada akhirnya terbebas untuk membayarkan pajak sesuai tarif yang sudah ditentukan. Mereka menanamkan dananya di Negara dengan pajak kecil yang merupakan tax heaven country. Pendapatan dan aset yang dimiliki tidak dilaporkan seluruhnya untuk mengindari pembayaran pajak yang besar, namun pemerintah kesulitan dalam membuktikan keberadaan kepemilikan assetaset tersebut karena belum terbukanya arus informasi antar Negara . Sejauh ini ada beberapa modus penghindaran pajak yang dilakukan oleh berbagai perusahaan seiring dengan bergulirnya era globalisasi di mana sekat-sekat negara menjadi semakin tipis. Hal ini dikarenakan pajak dianggap sebagai salah satu beban pengeluaran perusahaan yang harus ditekan serendah mungkin.

Baru-baru ini dunia dikejutkan dengan pemberitaan tentang skandal Panama Papers. Skandal Panama Papers adalah sebutan untuk bocornya klien firma hukum bernama Mossack Fonseca yang berbasis di Panama. Dalam list tersebut mengungkap 11,5 juta rekaman yang melibatkan 214.000 entitas offshore, 500 bank berskala internasional, serta individu dan perusahaan di 200 negara di seluruh dunia termasuk Indonesia. Sedikitnya 140 politisi, termasuk 12 pemimpin dan mantan pemimpin negara, selebritas, dan bintang olahraga disebut dalam dokumen yang mengungkap aneka dugaan praktik skandal keuangan rahasia.

Salah satu kebocoran dokumen finansial terbesar dalam sejarah mengguncang perhatian global pertengahan tahun 2016. Kebocoran itu berasal dari dokumen firma hukum Mossack Fonseca yang berbasis di Panama sehingga disebut sebagai "Panama Papers". Sedikitnya 140 politisi, termasuk 12 pemimpin dan mantan pemimpin negara, selebritas, dan bintang olahraga disebut dalam dokumen yang mengungkap aneka dugaan praktik skandal keuangan rahasia.

Bisa dibilang perusahaan yang ada dalam Panama Papers merupakan perusahaan yang bergerak dalam industri ekonomi bawah tanah (underground economy). Perekonomian bawah tanah dilakukan untuk sejauh mungkin menghindar atau tidak memenuhi aturan-aturan formal yang berlaku. Berbagai bentuk penyimpangan, pelanggaran atau tindakan yang bertentangan dengan peraturan yang berlaku seperti dibidang perpajakan, perbuatan penyuapan, penyimpangan dibidang devisa (peraturan control devisa) atau tindakan kriminal lainnya merupakan tindakan-tindakan yang akrab dengan kegiatan ekonomi bawah tanah, akan tetapi lantas bagaimana dengan skandal Panama Papers ini, apakah sebuah perbuatan yang melanggar hukum atau tidak?

Jutaan dokumen itu memuat mengenai individu dan entitas bisnis yang memanfaatkan perusahaan offshore untuk menghindari pajak dan melakukan pencucian uang. Terkait hal itu pemerintah perlu menjalin kerjasama dengan negara lain untuk menelusuri daftar orang-orang Indonesia yang masuk dalam daftar itu. Kelanjutan dari informasi tentang Panama Papers tersebut, Pemerintah Indonesia langsung bereaksi. Dipikirkan jalan keluar untuk menggiring agar dana milik warganegara Indonesia kembali ke dalam Negeri. Dicari jalan keluar agar dengan penuh kesadaran dana-dana yang telah terlanjur diparkir di luar negeri tersebut dapat ditarik kembali.

Pada umumnya perusahaan yang menjadi target para pengusaha Indonesia adalah perusahaan-perusahaan di negara yang memiliki Perjanjian Perpajakan (Tax Treaty). Tax treaty adalah perjanjian perpajakan antara dua negara yang dibuat dalam rangka meminimalisir pepajakan berganda dan berbagai usaha penghindaran pajak. Perjanjian ini digunakan oleh penduduk dua negara untuk menentukan aspek perpajakan yang timbul dari suatu transaksi di antara mereka. Penentuan aspek perpajakan tersebut dilakukan berdasarkan klausul-klausul yang terdapat dalam tax treaty yang bersangkutan sesuai jenis transaksi yang sedang dihadapi. Selain berorientasi kepada sesama negara yang sepakat dalam Tax Treaty, para pengusaha juga mencari dan berorientasi kepada negara yang merupakan masuk dalam kategori Tax Heaven. 
Tax Heaven adalah suatu bentuk negara yang menerapkan sistem perpajakan yang tidak sesuai dengan standar pajak internasional. Tax Haven merupakan istilah yang diberikan kepada negara-negara yang tidak membebankan pajak atau membebankan pajak dalam jumlah minimal. Tax Haven sendiri sudah cukup dikenal oleh kalangan pebisnis karena memberikan kemudahan perpajakan dan memiliki sistem kerahasiaan bank yang sangat ketat, oleh sebab itu sangat sulit sekali untuk memperoleh data informasi nasabah dari bank-bank yang beroperasi di Tax Haven (Bismar Nasution \& Dr. Sunarmi: 2013) dan Panama masuk dalam kategori Tax heaven.

Kemudian timbul pertanyaan, apakah nama-nama yang tercantum dalam Panama Papers tersebut sebagai pihak yang bersalah dimata hukum? Mereka tidak otomatis bersalah sebelum dinyatakan oleh otoritas pajak. Wajib pajak tersebut harus menjelaskan dan klarifikasi untuk membuktikan dengan jelas bahwasanya tindakan yang dilakukan bukan merupakan suatu kesalahan. Namun demikian tentunya merupakan suatu kesalahan jika mendirikan perusahaan atau badan hukum bayangan dengan tujuan agar dapat menyembunyikan harta sehingga akan dapat terhindar dari kewajiban perpajakan, dan ini yang disebut sebagai penggelapan pajak, tentu saja merupakan suatu pelanggaran hukum

Undang-undang tentang pengampunan pajak telah dikeluarkan sejak tanggal 16 Juli 2016. Dalam UU pengampunan pajak (UU tax amnesty) diberikan kesempatan para investor yang menanamkan uangnya di luar negeri untuk segera menarik kembali dan diinvestasikan di dalam negeri. Untuk itu mereka dibebaskan dari jeratan hukum pidana dan dibebaskan dari pemeriksaan oleh otoritas pajak atas asal muasal kekayaan mereka kecuali kekayaan yang berasal dari tindak pidana teroris, narkoba dan perdagangan manusia, walaupun hal ini juga menimbulkan pro dan kontra dari sejumlah kalangan.

Beragam sikap Wajib Pajak atas keluarnya UU pengampunan pajak tersebut, ada yang menanggapinya dengan apatis dan pesimis program tersebut tidak akan berjalan dengan baik dan tidak akan banyak manfaatnya, sehingga tidak akan mengikuti program tersebut. Namun di lain pihak banyak juga yang optimis dan menyambut dengan baik kebijakan tersebut dan tentu saja memanfaatkan program ini dengan baik.

Lantas apa hubungan pengampunan pajak dengan Panama Papers ini? UU Pajak bisa dibilang memiliki tujuan dalam rangka mendukung pemerintah terkait penerimaan negara berupa pajak dan melihat banyak orang Indonesia yang menyimpan harta mereka diluar negeri karena takut dibebani pajak maka RUU Pengampunan Pajak merupakan salah satu cara untuk mendeteksi dan melonggarkan aturan agar uang rakyat Indonesia yang ada diluar negeri masuk dan kembali ke Indonesia. Tentu saja bukan perkara mudah untuk melaksanakan rencana Pemerintah tersebut, diperlukan upaya pendekatan persuasif yang baik agar investor yang juga notabene sebagai Wajib Pajak tersebut percaya pada janji Pemerintah sehingga secara sukarela mau mengungkapkan harta kekayaannya tersebut, bahkan mau memindahkannya ke Indonesia.

Arti secara sederhana dari pengampunan pajak (tax amnesty) adalah adanya penghapusan pajak bagi Wajib Pajak (WP) yang menyimpan dananya di luar negeri dan didalam negeri tidak memenuhi kewajibannya dalam membayar pajak dengan imbalan menyetor pajak dengan tarif lebih rendah. Dengan dilakukannya pengampunan pajak ini, diharapkan para pengusaha yang menyimpan dananya di luar negeri akan memindahkan dananya di Indonesia dan menjadi WP baru yang patuh sehingga dapat meningkatkan pendapatan pajak negara. Dari pemberitaan CNN Indonesia dinyatakan bahwa banyak orang kaya di Indonesia yang menyimpan uang mereka di luar negeri, seperti Singapura, dengan memanfaatkan tax treaty. Oleh karena itulah Direktorat Jenderal Pajak (DJP) mendorong diberlakukannya pengampunan pajak ini untuk menarik kembali uang milik warga Indonesia yang disimpan di luar negeri.

Bicara mengenai kepatuhan pajak, menurut data Bappenas, tax coverage ratio Indonesia masih relatif rendah. Belum tercapainya target penerimaan pajak, menurut laporan Badan Pengawasan Keuangan dan Pembangunan (BPKP) tahun 2000, terdapat perbedaan (gap) antara perhitungan potensi pajak teoritis dengan hasil realisasi penerimaan. Sementara itu laporan kinerja 
Direktorat Jenderal Pajak tahun 2000 yang dikeluarkan oleh Badan Analisa Keuangan dan Moneter (BAKM) menyebutkan bahwa tax coverage ratio masih rendah.

Ada dua implikasi utama berkaitan dengan rendahnya tax coverage ratio. Pertama, pada satu sisi mencerminkan rendahnya kepatuhan pajak (tax compliance) masyarakat sehingga jumlah pajak yang berhasil dikumpulkan masih relatif sedikit dibandingkan dengan basis pajak (tax base) yang ada. Kedua, relatif rendahnya jumlah pajak yang dikumpulkan dibanding dengan basis pajak yang ada juga memberikan harapan untuk peningkatan peneriman pajak selanjutnya. Dengan kata lain, masih tersedia ruang bagi pemerintah untuk meningkatkan penerimaan pajak. Menurut Simon (2003), pengertian kepatuhan pajak (tax compliance) adalah wajib pajak mempunyai kesediaan untuk memenuhi kewajiban pajaknya.

Pemenuhan kewajiban perpajakan tersebut harus sesuai dengan aturan yang berlaku tanpa perlu ada pemeriksaan, investigasi seksama (obtrusive investigation), peringatan, ancaman, dan penerapan sanksi baik hukum maupun administrasi. Kepatuhan wajib pajak memenuhi kewajiban perpajakannya akan meningkatkan penerimaan negara dan pada gilirannya akan meningkatkan besarnya rasio pajak (Safri Nurmantu, 2007).

Kita perlu memahami terlebih dahulu definisi kepatuhan pajak untuk mengetahui lebih lanjut cara mengukur tingkat kepatuhan. Sayangnya, meski riset terkait perpajakan sudah berlangsung lebih dari 40 tahun, sampai saat ini belum ada konsensus mengenai apa yang dimakud dengan 'perilaku patuh pajak'. Meski demikian, dari banyak definisi yang ada, secara garis besar definisi kepatuhan pajak bisa dibagi dalam dua kelompok besar.

Dari sisi kegunaan, pendekatan konseptual memiliki kelemahan: ambiguitas. Misalnya, terdapat perbedaan pendapat mengenai apakah tindakan tax avoidance (menghindari pajak) perlu dimasukkan dalam definisi konseptual kepatuhan pajak. Meski dalam banyak kasus bisa ditentukan secara mudah bahwa tax avoidance adalah legal dan tax evasion (menyembunyikan pajak) adalah illegal, dalam beberapa kasus pertimbangan moral mutlak diperlukan untuk bisa memilahnya. Tentu ini menimbulkan masalah baru karena pertimbangan moral rentan subjektifitas.

Fenomena inilah yang kemudian memunculkan istilah hibrid 'tax avoision'. Singkat kata, tingkat kepatuhan pajak tidak mudah untuk ditentukan, apalagi diukur, jika definisi konpseptual digunakan. Pendekatan operasional bisa digunakan untuk menutupi kelemahan ini.

Kepatuhan pajak atau Tax Compliance diartikan sebagai kondisi ideal wajib pajak yang memenuhi peraturan perpajakan serta melaporkan penghasilannya secara akurat dan jujur. Kondisi ideal tersebut bisa menciptakan kepatuhan pajak, yang didefinisikan sebagai suatu keadaan wajib pajak yang memenuhi semua kewajiban perpajakan dan melaksanakan hak perpajakannya dalam bentuk formal dan kepatuhan material. Konsep kepatuhan perpajakan di atas sesuai dengan pendapat Yoingco (1997) yang menyebutkan tingkat kepatuhan perpajakan sukarela memiliki tiga aspek yaitu aspek formal, material (honestly), dan pelaporan (reporting).

Dalam sistem self assessment, Wajib Pajak diberi kepercayaan untuk menghitung, membayar, dan melaporkan jumlah pajak yang terhutang. Sistem self assesment diterapkan atas dasar kepercayaan pihak otoritas pajak kepada wajib pajak. Implikasi dari sistem ini adalah bahwa instansi yang bertugas memungut pajak harus memiliki kemampuan baik untuk mengadministrasikan pajak, serta wajib pajak harus diawasi oleh fiskus sehingga dapat diketahui apakah kewajiban perpajakan telah dijalankan dengan benar oleh Wajib Pajak.

Selain kepatuhan formal, pengukuran kepatuhan wajib pajak juga harus dilihat dari sisi kepatuhan material dimana tingkat kebenaran nominal pelaporan kewajiban pajak akan dilihat. Dengan stelsel self assessment yang dianut di Indonesia otomatis kesadaran wajib pajak untuk melakukan pelaporan yang benar menjadi hal yang sangat diharapkan. Bisa saja terjadi seorang Wajib pajak selalu melaporkan kewajibn pajaknya tepat waktu, namun nilai yang dilaporkan bukanlah nilai yang sebenarnya, maka Wajib Pajak tersebut sudah menjadi Wajib Pajak patuh secara formal namun belum memenuhi kewajiban pajak secara material. 
Penelitian mengenai kepatuhan pajak sudah dilakukan oleh beberapa peneliti dengan menggunakan kerangka model Theory of Planned Behavior (TPB) untuk menjelaskan perilaku kepatuhan pajak Wajib Pajak Orang Pribadi (Bobek, 2003). Model TPB yang digunakan dalam penelitian memberikan penjelasan yang signifikan, bahwa perilaku tidak patuh (noncompliance) Wajib Pajak sangat dipengaruhi oleh variabel sikap, norma subyektif, dan kontrol keperilakuan yang dipersepsikan. Bradley (1994) melakukan penelitian kepatuhan Wajib Pajak Badan dengan responden tax professional. Tax professional adalah orang profesional di perusahaan yang ahli di bidang perpajakan. Oleh karena itu, untuk menjelaskan perilaku Wajib Pajak Badan yang dalam hal ini diwakili oleh tax professional perlu menggunakan teori perilaku individu dan perilaku organisasi.

Tidak dapat disangkal, masih banyak orang yang menganggap bahwa tidak ada gunanya membayar pajak. Terlebih lagi asumsi masyarakat setelah terjadinya kasus penyelewengan pajak yang semakin memperparah pandangan masyarakat akan sistem pengelolaan perpajakan di indonesia. Selain itu, pemahaman Wajib Pajak yang lemah dapat terjadi karena peraturan pajak yang dinamis.

Sesuai dengan sifatnya yang dinamis, pajak selalu mengikuti perkembangan kehidupan sosial dan ekonomi negara serta masyarakatnya. Ketidaktahuan masyarakat akan perubahan peraturan dan sistem perpajakan akan berakibat berkurangnya pemahaman terhadap hak dan kewajkiban perpajakannya, sehingga mempengaruhi pula pada tingkat kepatuhan untuk menjalankan kewajiban perpajakan.

Pemerintah telah menetapkan kriteria wajib pajak patuh berdasarkan Keputusan Menteri Dalam Negeri No. 235/KMDN.03/2004 dimana salah satunya adalah wajib pajak telah tepat waktu dalam menyampaikan Surat Pemerintahuan untuk semua jenis pajak dalam dua tahun terakhir.

Fenomena-fenomena tersebut kita lihat terjadi di sangat banyak kota di Indonesia, baik di kota dengan tingkat pendapatan penduduknya yang relatif tinggi, apalagi di kota yang tingkat pendapatan penduduknya relatif rendah. Dalam penelitian ini akan dilakukan di Bekasi. Adapun Bekasi yang terpilih untuk dilakukan penelitian dengan pertimbangan bahwa di Bekasi banyak bernaung industri- industri besar antara lain Kawasan Industri M 2100, Kawasan Industri Cikarang Baru, Kawasan Jababeka, Kawasan Marunda Center, serta banyak pula kawasan industri baru yang merupakan Wajib Pajak potensial yang akan menjadi sumber penerimaan pajak Bekasi. Dengan demikian secara ekonomi Bekasi bisa memberikan kontribusi yang sangat besar terhadap perekonomian nasional.

Dengan melihat fenomena tersebut, maka penulis terdorong untuk melakukan penelitian dengan judul penelitian "Pengaruh Respon dan Keikutsertaan Wajib Pajak dalam Program Tax Amnesty terhadap Kepatuhan Wajib Pajak di Bekasi “

Berdasarkan uraian latar belakang di atas, maka rumusan masalah dalam penelitian ini adalah seperti berikut ini.

1) Apakah terdapat pengaruh atas respon Wajib Pajak atas program tax amnesty terhadap keikutsertaan Wajib Pajak dalam program pengampunan pajak di Bekasi

2) Apakah terdapat pengaruh atas respon Wajib Pajak atas program tax amnesty terhadap kepatuhan formal Wajib Pajak di Bekasi.

3) Apakah terdapat pengaruh atas keikutsertaan Wajib Pajak atas program tax amnesty terhadap kepatuhan formal Wajib Pajak di Bekasi.

4) Apakah terdapat pengaruh atas respon Wajib Pajak atas program tax amnesty terhadap kepatuhan material Wajib Pajak di Bekasi.

5) Apakah terdapat pengaruh atas kepatuhan formal Wajib Pajak terhadap kepatuhan material Wajib Pajak di Bekasi

6) Apakah terdapat pengaruh atas keikutsertaan Wajib Pajak atas program tax amnesty terhadap kepatuhan material Wajib Pajak di Bekasi. 


\section{KAJIAN LITERATUR}

Penelitian ini didasarkan atas teori tentang kepatuhan, dimana terdapat dua pendekatan teori kepatuhan, yaitu pendekatan teori ilmu ekonomi dan pendekatan teori psikologi, Trivedi, et al (2005). Pendekatan teori ilmu ekonomi menekankan insentif, sedangkan teori berbasis psikologi menekankan sikap.

Berdasarkan teori ilmu ekonomi atas kepatuhan, diisyaratkan bahwa kepatuhan pajak dipengaruhi beberapa pertimbangan seberapa besar kemungkinan mereka akan dikenai konsekuensi-konsekuensi ekonomi dari berbagai alternatif kepatuhan, seperti apakah perlu menghindari pajak atau tidak, probabilita tindakannya diketahui dan berbagai konsekuensinya, kemudian memilih berbagai alternatif yang akan memaksimumkan tingkat pengembalian sesudah pajak yang mereka harapkan (expected after tax return). Sedangkan berdasarkan teori psikologi mengasumsikan bahwa ada berbagai faktor psikologis, termasuk kewajiban moral dan masalah etika serta kejujuran, yang juga penting bagi Wajib Pajak.

Pajak secara umum diartikan sebagai bentuk iuran/pembayaran wajib masyarakat kepada negara yang pelaksanaannya berdasarkan undang-undang. Terdapat banyak pengertian. atau definisi pajak yang disampaikan oleh para ahli. Pengertian pajak menurut Rochmat Soemitro (2005) "Pajak adalah iuran rakyat kepada kas negara (peralihan kekayaan dari sektor swasta ke sektor pemerintahan) dengan tidak mendapat jasa timbal (tegen prestatie) yang langsung dapat ditunjuk dan digunakan untuk membiayai pengeluaran umum. Pengertian pajak menurut UndangUndang No. 28 tahun 2007 adalah kontribusi wajib kepada Negara yang terutang oleh orang pribadi atau badan yang bersifat memaksa berdasarkan undang-undang dengan tidak mendapatkan imbalan secara langsung.

Pajak dari perspektif ekonomi dipahami sebagai beralihnya sumber daya dari sektor privat kepada sektor publik. Pemahaman ini memberikan gambaran bahwa adanya pajak menyebabkan dua situasi menjadi berubah. Pertama, berkurangnya kemampuan individu dalam menguasai sumber daya untuk kepentingan penguasaan barang dan jasa. Kedua, bertambahnya kemampuan keuangan negara dalam penyediaan barang dan jasa publik yang merupakan kebutuhan masyarakat.

Dalam pemungutan pajak didasarkan pada asas-asas tertentu bagi fiskus sehingga dengan asas ini negara memberi hak kepada dirinya sendiri untuk memungut pajak dari penduduknya, yang pada hakekatnya memungut dengan paksa (berdasarkan undang-undang) sebagian dari harta yang dimiliki penduduknya (Rochmat Soemitro:2004). Asas-asas pemungutan pajak tersebut adalah asas domisili, asas sumber dan asas kebangsaan.

Fungsi anggaran (budgeter) atau fungsi fiskal merupakan fungsi utama pajak, pajak dipergunakan sebagai alat untuk menghimpun dana yang akan dipergunakan untuk membiayai penyelenggaraan pemerintahan yang dilakukan melalui sistem pemungutan pajak berdasarkan undang-undang perpajakan yang berlaku. Disebut fungsi utama karena fungsi inilah yang secara historis pertama kali muncul. Pajak digunakan sebagai alat untuk menghimpun dana dari masyarakat tanpa ada kontraprestasi secara langsung. Pajak berfungsi untuk memasukkan uang dari sektor swasta (rakyat) ke dalam kas negara atau anggaran negara. Berdasarkan fungsi inilah pemerintah sebagai pihak yang membutuhkan dana untuk membiayai berbagai kepentingan melakukan upaya pemungutan dari warga negaranya.

Fungsi regurelend disebut juga fungsi mengatur, yaitu pajak merupakan alat kebijakan pemerintah untuk mencapai tujuan tertentu di luar bidang keuangan/fiskal. Pajak dipergunakan sebagai alat penggerak masyarakat dalam sarana perekonomian untuk meningkatkan kesejahteraan rakyat. Fungsi mengatur dengan menggunakan pajak bertujuan untuk mendorong dan mengendalikan keinginan masyarakat agar sejalan dengan keinginan dan rencana pemerintah, meskipun dari sisi penerimaan kadangkala tidak menguntungkan. 
Dalam sistem perpajakan dikenal ada tiga sistem pemungutan pajak yaitu; official assessment system, self assessment system, dan withholding system. Indonesia saat ini menerapkan self assessment system untuk pajak penghasilan. Official Assessment System.Merupakan sistem pemungutan pajak dimana inisiatif untuk memenuhi kewajiban perpajakan berada pada pihak fiskus. Dalam sistem ini fiskus yang bersifat aktif, mulai dari menentukan Wajib Pajak yang akan diberikan NPWP sampai dengan penetapan jumlah pajak terutang melalui mekanisme penerbitan Surat Ketetapan Pajak (SKP). Ciri-ciri official assessment system adalah: 1) wewenang untuk menentukan besarnya pajak terutang ada pada fiskus, 2) Wajib Pajak bersifat pasif, 3)utang pajak timbul setelah dikeluarkannya SKP oleh fiskus.

Dalam sistem official assessment besarnya kewajiban pajak yang harus dibayar oleh wajib pajak ditentukan sepenuhnya oleh fiskus selaku pemungut pajak. Dalam Undang-Undang Ketentuan Umum dan Tata Cara Perpajakan Tahun 2007 terdapat beberapa macam SKP yaitu 1)SKP Kurang Bayar (SKPKB),SKP Lebih Bayar (SKPLB), SKP Nihil (SKPN), SKP Kurang Bayar Tambahan (SKPKBT). Wajib Pajak yang menerima SKP adalah Wajib Pajak yang telah melalui pemeriksaan pajak. Sistem ini pada umumnya diterapkan terhadap jenis pajak yang melibatkan masyarakat luas dari semua lapisan, dimana masyarakat selaku subjek pajak dipandang belum mampu diserahi tanggung jawab untuk menghitung dan menetapkan sendiri pajaknya, misalnya Pajak Bumi dan Bangunan (PBB).

Self Assessment System merupakan sistem pemungutan pajak, dimana wewenang untuk menentukan besarnya pajak terutang sepenuhnya berada pada Wajib Pajak. Wajib pajak diberi wewenang untuk menghitung, memperhitungkan, menyetor dan melaporkan sendiri pajaknya. Keterlibatan fiskus ada apabila wajib pajak menyalahi aturan perpajakan. Ciri-ciri self assessment system adalah 1) wewenang untuk menentukan besarnya pajak terutang ada pada Wajib Pajak, 2)Wajib Pajak aktif, mulai dari menghitung, menyetorkan dan melaporkan sendiri pajak yang terutang, 3) fiskus tidak ikut campur, hanya mengawasi. Self assessment system memberikan kepercayaan yang besar kepada Wajib Pajak untuk menghitung, membayar, dan melaporkan sendiri pajaknya, dan akan berhasil dengan baik apabila Wajib Pajak telah memenuhi syarat-syarat 1) kesadaran pajak Wajib Pajak (tax consciousness), 2) Kejujuran Wajib Pajak (tax honesty), 3) Keinginan untuk membayar pajak Wajib Pajak (tax mindedness)4) kedisiplinan Wajib Pajak di dalam melaksanakan peraturan-peraturan perpajakan (tax dicipline).

Withholding System memberikan wewenang pemungutan pajak kepada pihak ketiga, dimana pihak ketiga diberi wewenang untuk memotong atau memungut besarnya pajak terutang. Pihak ketiga dapat berupa Wajib Pajak Orang Pribadi atau Wajib Pajak Badan dalam negeri. Pajak yang dipotong atau dipungut oleh pihak ketiga adalah pajak yang dapat dikreditkan atau diperhitungkan kembali pada akhir tahun pajak atau seluruh pajak penghasilan terutang dari wajib pajak, misalnya pajak penghasilan $(\mathrm{PPh})$ pasal 21, dimana pemberi kerja, bendaharawan pemerintah, dana pensiun diserahi tanggung jawab untuk memotong pajak atas penghasilan yang dibayarkan.

Tax amnesty (Pengampunan pajak) adalah penghapusan pajak yang seharusnya terutang, tidak dikenai sanksi administrasi perpajakan dan sanksi pidana di bidang perpajakan dengan cara mengungkap Harta dan membayar Uang Tebusan sebagaimana diatur dalam Undang-Undang ini. Dari pengertian tersebut sudah jelas bahwa bagi Wajib Pajak yang mengikuti tax amnesty maka kepadanya mendapatkan keuntungan diantaranya adalah penghapusan pajak yang seharusnya terutang, tidak dikenai sanksi administrasi perpajakan dan sanksi pidana di bidang perpajakan.

Misalnya seorang Wajib Pajak tidak pernah melaporkan SPT (Surat Pemberitahuan) baik Masa maupun Tahunan dari tahun 2011 sampai dengan 2015. Apabila Wajib Pajak tersebut mengikuti tax amnesty maka pajak yang seharusnya terutang dan sanksi/denda yang seharusnya dibayar menjadi hilang atau dihapus dengan cara mengungkapkan seluruh hartanya dan membayar uang tebusan. Maksud dari uang tebusan adalah sejumlah uang yang dibayarkan ke kas negara untuk mendapatkan pengampunan pajak. Nantinya uang tebusan ini secara resmi masuk ke Kas Negara dan dapat digunakan untuk membiayai pembangunan. 
Sebagaimana dijelaskan dalam Undang-undang No 11 Tahun 2016 tentang Pengampunan Pajak bahwa pertumbuhan ekonomi nasional dalam beberapa tahun terakhir cenderung mengalami perlambatan yang berdampak pada turunnya penerimaan pajak dan juga telah mengurangi ketersediaan likuiditas dalam negeri yang sangat diperlukan untuk meningkatkan pertumbuhan ekonomi Indonesia. Di sisi lain, banyak Harta warga negara Indonesia yang ditempatkan di luar wilayah Negara Kesatuan Republik Indonesia, baik dalam bentuk likuid maupun nonlikuid, yang seharusnya dapat dimanfaatkan untuk menambah likuiditas dalam negeri yang dapat mendorong pertumbuhan ekonomi nasional.

Namun tidak semua harta tersebut telah dilaporkan di dalam SPT Tahunan oleh pemiliknya, bahkan mungkin banyak yang belum terungkap. Apabila harta yang belum diungkapkan tersebut pada akhirnya di laporkan dalam SPT Tahunan atau terungkap oleh Direktorat Jenderal Pajak maka berdasarkan ketentuan perpajakan secara umum atas harta tersebut dapat dikenai $\mathrm{PPh}$ atau PPN kurang bayar atau dapat ditagih kembali pajak-pajaknya. Atas konsekuensi adanya pajak yang masih harus dibayar inilah yang menjadikan mereka tidak mau mengungkapkan hartanya yang ada di luar negeri dengan sukarela.

Bagi banyak negara, pengampunan pajak (tax amnesty) seringkali dijadikan alat untuk menghimpun penerimaan negara dari sektor pajak (tax revenue) secara cepat dalam jangka waktu yang relatif singkat. Program tax amnesty ini dilaksanakan karena semakin parahnya upaya penghindaran pajak. Kebijakan ini dapat memperoleh manfaat perolehan dana, terutama kembalinya dana yang disimpan di luar negeri, dan kebijakan ini dalam mempunyai kelemahan dalam jangka panjang dapat berakibat buruk berupa menurunnya kepatuhan sukarela (voluntary compliance) dari wajib pajak patuh, bilamana tax amnesty dilaksanakan dengan program yang tidak tepat.

Berdasarkan penelitian (Enste \& Schneider, 2002), bahwa besarnya persentase kegiatan ekonomi bawah tanah (underground economy), di negara maju dapat mencapai 14-16 persen dari Produk Domestik Bruto (PDB), sedangkan di negara berkembang dapat mencapai 35 - 44 persen dari PDB. Kegiatan ekonomi bawah tanah ini tidak pernah dilaporkan sebagai penghasilan dalam formulir surat pemberitahuan tahunan (SPT) Pajak Penghasilan, sehingga masuk dalam kriteria penyelundupan pajak (tax evasion). Penyelundupan pajak mengakibatkan beban pajak yang harus dipikul oleh para wajib pajak yang jujur membayar pajak menjadi lebih berat, dan hal ini mengakibatkan ketidakadilan yang tinggi. Peningkatan kegiatan ekonomi bawah tanah yang dibarengi dengan penyelundupan pajak ini sangat merugikan negara karena berarti hilangnya penerimaan pajak yang sangat dibutuhkan untuk membiayaai program pendidikan, kesehatan dan program-program pengentasan kemiskinan lainnya. Oleh sebab itu timbul pemikiran untuk mengenakan kembali pajak yang belum dibayar dari kegiatan ekonomi bawah tanah tersebut melalui program khusus yakni pengampunan pajak .

Pengertian kepatuhan adalah suatu kondisi yang tercipta dan berbentuk melalui proses dari serangkaian perilaku yang menunjukkan nilai-nilai ketaatan, kepatuhan, kesetiaan, keteraturan dan ketertiban. Sikap atau perbuatan yang dilakukan bukan lagi atau sama sekali tidak dirasakan sebagai beban, bahkan sebaliknya akan mebebani dirinya bila mana ia tidak dapat berbuat sebagaimana lazimnya. Prijadarminto (2003), Hasibuan (2007) menjelaskan bahwa kepatuhan merupakan kesadaran dan kesediaan seseorang mentaati semua peraturan dan norma-norma sosial yang berlaku. Kepatuhan yang baik mencerminkan besarnya rasa tanggung jawab seseorang terhadap tugas-tugas yang diberikan kepadanya. Hal ini mendorong gairah kerja, semangat kerja, dan terwujudnya tujuan masyarakat, maka setiap orang harus berusaha agar mempunyai kepatuhan yang baik.

Teori kepatuhan telah diteliti pada ilmu-ilmu sosial khususnya dibidang psikologis dan sosiologi yang lebih menekankan pada pentingnya proses sosialisasi dalam mempengaruhi perilaku kepatuhan seorang individu. Menurut Tyler (2004) terdapat dua perspektif dalam literatur sosiologi mengenai kepatuhan kepada hukum, yang disebut instrumental dan normatif. Perspektif 
instrumental mengasumsikan individu secara utuh didorong oleh kepentingan pribadi dan tanggapan terhadap perubahan-perubahan yang berhubungan dengan perilaku. Perspektif normatif berhubungan dengan apa yang orang anggap sebagai moral dan berlawanan dengan kepentingan pribadi.

Seorang individu cenderung mematuhi hukum yang mereka anggap sesuai dan konsisten dengan norma-norma internal mereka. Komitmen normatif melalui moralitas personal (normative commitment through morality) berarti mematuhi hukum karena hukum tersebut dianggap sebagai suatu keharusan, sedangkan komitmen normatif melalui legitimasi (normative commitment through legitimaty) berarti mematuhi peraturan karena otoritas penyusun hukum tersebut memiliki hak untuk mendikte perilaku.

Salah satu faktor yang berpengaruh dari teori kepatuhan dalam dunia medis adalah pemahaman tentang instruksi. Tidak seorangpun dapat mematuhi instruksi, jika ia salah paham tentang instruksi yang diterima. Ley dan Spetman (2002), menemukan bahwa lebih dari $60 \%$ yang diwawancarai setelah bertemu dokter salah mengerti tentang instraksi yang diberikan kepada mereka. Hal ini disebabkan kegagalan petugas kesehatan dalam memberikan informasi yang lengkap dan banyaknya instruksi yang harus diingat dan penggunaan istilah medis.

Dalam hal pajak, aturan yang berlaku adalah aturan perpajakan. Jadi dalam hubungannya dengan Wajib Pajak yang patuh, maka pengertian kepatuhan pajak merupakan suatu ketaatan untuk melakukan ketentuan-ketentuan atas aturan-aturan perpajakan yang diwajibkan atau diharuskan untuk dilaksanakan Kiryanto (2000).

Menurut Simon (2003) pengertian kepatuhan pajak (tax compliance) adalah wajib pajak mempunyai kesediaan untuk memenuhi kewajiban pajaknya. Pemenuhan kewajiban perpajakan tersebut harus sesuai dengan aturan yang berlaku tanpa perlu ada pemeriksaan, investigasi seksama (obtrusive investigation), peringatan, ancaman, dan penerapan sanksi baik hukum maupun administrasi. Kepatuhan Wajib Pajak memenuhi kewajiban perpajakannya akan meningkatkan penerimaan negara dan pada gilirannya akan meningkatkan besarnya rasio pajak (Safri Nurmantu, 2007). Melayani wajib pajak berarti melakukan komunikasi dengan wajib pajak.

Menurut Errard dan Feinstein pengertian kepatuhan pajak adalah rasa bersalah dan rasa malu, persepsi Wajib Pajak atas kewajaran dan keadilan beban pajak yang mereka tanggung, dan pengaruh kepuasan terhadap pelayanan pemerintah. Safri Nurmanto mengatakan bahwa kepatuhan perpajakan dapat didefinisikan sebagai suatu keadaan di mana Wajib Pajak memenuhi semua kewajiban perpajakan dan melaksanakan hak perpajakannya.

Kepatuhan Wajib Pajak merupakan pemenuhan kewajiban perpajakan yang dilakukan oleh pembayar pajak dalam rangka memberikan kontribusi bagi pembangunan dewasa ini yang diharapkan di dalam pemenuhannya diberikan secara sukarela. Kepatuhan Wajib Pajak menjadi aspek penting mengingat sistem perpajakan Indonesia menganut sistem Self Asessment di mana dalam prosesnya secara mutlak memberikan kepercayaan kepada Wajib Pajak untuk menghitung, membayar dan melapor kewajibannya.

Kepatuhan pajak adalah kunci utama dalam sistem self assessment. Karena apabila Wajib Pajak tidak patuh akan menimbulkan keinginan untuk melakukan penghindaran, pengelakan, penyelundupan dan melalaikan pajak. Kondisi perpajakan yang menuntut peran aktif wajib pajak dalam melaksanakan kewajiban perpajakannya memerlukan kepatuhan yang tinggi. Kepatuhan yaitu kepatuhan dalam pemenuhan kewajiban perpajakan yang sesuai dengan ketentuan perpajakan. Menurut Machfud Sidik kepatuhan memenuhi kewajiban perpajakan secara sukarela (voluntary of compliance) merupakan tulang punggung sistem self assessment. Wajib Pajak bertanggung jawab menentukan sendiri kewajiban perpajakan dengan benar dan tepat waktu dalam membayar dan melaporkannya

Pelopor studi tentang kepatuhan Wajib Pajak adalah Allingham dan Sandmo (1972). Allingham dan Sandmo menggunakan konsep expected utility untuk menjelaskan perilaku kepatuhan Wajib Pajak Sedangkan faktor non ekonomi yang berpengaruh pada perilaku 
ketidakpatuhan Wajib Pajak adalah tingkat pengetahuan dan pemahaman Wajib Pajak terhadap ketentuan perpajakan yang berlaku (Krause, 2000).

Menurut Safri Nurmantu (2005), kepatuhan pajak dapat didefinisikan sebagai suatu keadaan dimana Wajib Pajak memenuhi semua kewajiban perpajakan dan melaksanakan hak perpajakannya. Kepatuhan pajak meliputi kepatuhan formal dan kepatuhan material. Kepatuhan formal adalah keadaan dimana Wajib Pajak memenuhi kewajiban perpajakan secara formal sesuai dengan undang-undang perpajakan, misalnya tentang batas waktu penyampaian pelaporan. Kepatuhan material adalah suatu keadaan dimana Wajib Pajak secara substansi/hakekat memenuhi semua ketentuan material perpajakan, misalnya kebenaran pengisian dan kejujuran pengisian dalam SPT.

Ketidakpatuhan akan timbul apabila Wajib Pajak tidak mempunyai pengetahuan perpajakan yang memadai, sehingga wajib pajak secara tidak sengaja tidak melakukan kewajiban perpajakannya (tidak mendaftarkan untuk memperoleh NPWP, tidak menyampaikan SPT dsb) atau melakukan kewajiban perpajakan tetapi tidak sepenuhnya benar. Di lain pihak, pengetahuan dan pemahaman yang baik juga berdampak pada munculnya ketidakpatuhan, misalnya penghindaran pajak melalui rekayasa transaksi keuangan untuk mengeksploitasi kelemahan aturan perpajakan.

Owens dan Hamilton (2004) mengatakan bahwa urusan perpajakan harus bisa ditangani oleh orang-orang dengan usaha skala kecil, tanpa perlu bantuan sebuah perkumpulan akuntan pajak atau pengacara. Oleh karenanya otoritas pajak harus mampu menciptakan suatu sistem yang baik dan sederhana sehingga para pengusaha kecil tersebut dapat melakukan pengurusan pajak sendiri. Hal ini tentu saja akan dapat meningkatkan kepatuhan pajak.

Erard (1997) menyimpulkan bahwa skala usaha Wajib Pajak dapat berpengaruh pada kepatuhan wajib pajak dalam melaksanakan kewajiban perpajakan. Hal ini berkaitan dengan masalah efisiensi, yaitu besarnya biaya yang harus dikeluarkan oleh satu perusahaan untuk tetap patuh dibandingkan dengan jumlah pajak yang harus dibayar apabila Wajib Pajak tersebut tidak patuh dan terdeteksi oleh administrasi perpajakan. Sebagai contoh, Wajib Pajak perusahaan kecil mungkin tidak patuh karena tidak mempunyai pemahaman tentang teknis perpajakan yang memadai, tidak dapat mengikuti perkembangan aturan perpajakan, dan enggan menyewa konsultan perpajakan untuk menangani masalah perpajakan mereka karena pertimbangan efisiensi biaya.

Dalam penelitiannya, Wahyu Santoso (2008) juga menerangkan tentang salah satu faktor yang mempengaruhi tingkat kepatuhan wajib pajak yaitu status pemeriksaan. Wajib pajak yang telah diperiksa pada tahun sebelunya cenderung akan memiliki kepatuhan yang lebih tinggi daripada sebelum diperiksa. Artinya perusahaan yang pernah diperiksa, ceteris paribus, akan memiliki tingkat koreksi penghasilan netto yang lebih rendah. Atau dengan kata lain para wajib pajak yang pernah diperiksa akan memiliki tingkat kepatuhan rata-rata yang lebih tinggi daripada mereka yang belum pernah diperiksa.

Hasil penelitian yang dilakukan oleh Richardson (2006) menunjukkan bahwa Kebijakan upaya meningkatkan kepatuhan pajak harus mempertimbangkan konteks budaya di mana mereka diterapkan. Hal ini senada dengan penelitian yang dilakukan oleh Widi Widodo (2010), bahwa faktor demografi berpengaruh terhadap kepatuhan pajak. Hasil riset yang dilakukannya di Indonesia pada tahun 2009 menunjukan bahwa faktor pembentuk moralitas pajak yang paling dominan adalah faktor demografis dimana tingkat pendidikan Wajib Pajak sangat besar peranannya untuk menentukan kepatuhan terhadap pajak. Indikator demografis yang lain misalnya, tingkat pendapatan, gender, status pernikahan dan agama, ternyata tidak begitu dominan dalam menentukan moralitas seseorang untuk patuh terhadap pajak.

Wajib Pajak Patuh adalah Wajib Pajak yang ditetapkan oleh Direktur Jenderal Pajak sebagai Wajib Pajak yang memenuhi kriteria tertentu yang Dapat Diberikan Pengembalian Pendahuluan Kelebihan Pembayaran Pajak. Status Wajib Pajak Patuh, bisa diperoleh dengan dua cara yaitu dengan ditetapkan oleh KPP dimana Wajib Pajak terdaftar dan atas pengajuan Wajib Pajak sendiri untuk ditetapkan sebagai Wajib Pajak patuh. Dalam hal mengajukan permohonan, Wajib Pajak 
menyampaikan permohonan yang diajukan paling lambat 3 bulan sebelum tahun buku berakhir ke KPP tempat Wajib Pajak terdaftar.

Kita mengenal dua macam kapatuhan, yaitu Kepatuhan formal dan kepatuhan material. Kepatuhan formal adalah suatu keadaan dimana Wajib Pajak memenuhi kewajiban perpajakan dengan menitik beratkan pada nama dan bentuk kewajiban saja, tanpa memperhatikan hakekat kewajiban itu. Misalnya menyampaikan SPT PPh sebelum tanggal 31 Maret ke KPP, dengan mengabaikan apakah isi SPT PPh tersebut sudah benar atau belum. Sedangkan kepatuhan material adalah suatu keadaan di mana Wajib Pajak secara substantif (hakekat) memenuhi semua ketentuan material perpajakan, yaitu sesuai isi dan jiwa undang-undang perpajakan. Kepatuhan material meliputi juga kepatuhan formal.

Wajib Pajak yang berperilaku sekedar memenuhi kepatuhan formal mempunyai peranan yang besar terhadap rendahnya coverage ratio (angka yang menunjukkan perbandingan antara jumlah pajak yang terpungut dan jumlah potensi pajak mestinya dapat dipungut) pajak penghasilan di Indonesia yang menurut pengamatan sementara baru berkisar antara 35\%. Sebaliknya Wajib Pajak yang berperilaku memenuhi kepatuhan material mempunyai peranan yang besar dalam mempertinggi tax coverage ratio.

\subsection{Kerangka Pemikiran}

Pengampunan pajak (tax amnesty) adalah suatu kesempatan waktu yang terbatas pada kelompok pembayar pajak tertentu untuk membayar sejumlah tertentu dan dalam waktu tertentu berupa pengampunan kewajiban pajak (termasuk bunga dan denda) yang berkaitan dengan masa pajak sebelumnya atau periode tertentu tanpa takut hukuman pidana. Kebijakan pengampunan pajak sebenarnya pernah dilakukan Indonesia pada tahun 1984, namun saat itu bisa dikatakan kurang berhasil.

Efek jangka panjang yang diharapkan Pemerintah atas program pengampunan pajak adalah timbulnya kesadaran Wajib Pajak atas kewajibannya dalam perpajakan. Setelah mengikuti pengampunan pajak, wajib pajak menjadi lega dan tidak kawatir lagi akan dilakukan pemeriksaan oleh petugas pajak sampai dengan tahun pajak 2015. Untuk itu efek psikologinya, Wajib Pajak akan mengjaga ke "lega" an tersebut seterusnya. Oleh karenanya mereka akan berusaha menjadi Wajib Pajak patuh yang selalu memenuhi kewajiban pajaknya dengan selaku melakukan pembayaran dan pelaporan pajak sesuai dengan yang seharusnya.

Menurut Christian (2002) di negara Bagian Michigan, dua pertiga Wajib Pajak baru, dan sembilan dari sepuluh Wajib pajak lama yang telah melaksanakan program pengampunan pajak, akan kembali lagi melakukan pelaporan pajaknya dan melakukan pembayaran sesuai dengan yang seharusnya. Hal ini menjunjukkan bahwa program pengampunan pajak akan berpengaruh terhadap kepatuhan pajak

Hal senada juga ditulis dalam penelitian Tower, Ralph (2015) saat ada program pengampunan pajak, badan usaha komersial dan non komersial di Amerika selalu melakukan Internal audit untuk memastikan dilakukannya tax planning yang baik, menmbuat strategi yang baik agar terhindar dari kerugian atas kelalaian dalam kewajiban pajak. Setelah melakukan tax amnesty, walau dengan keterpaksaan mereka akan berusaha melakukan kewajiban pajak sebagaimana mestinya.

Hubungan antar variabel dalam penelitian dapat dilihat dalam kerangka pemikiran dibawah ini 


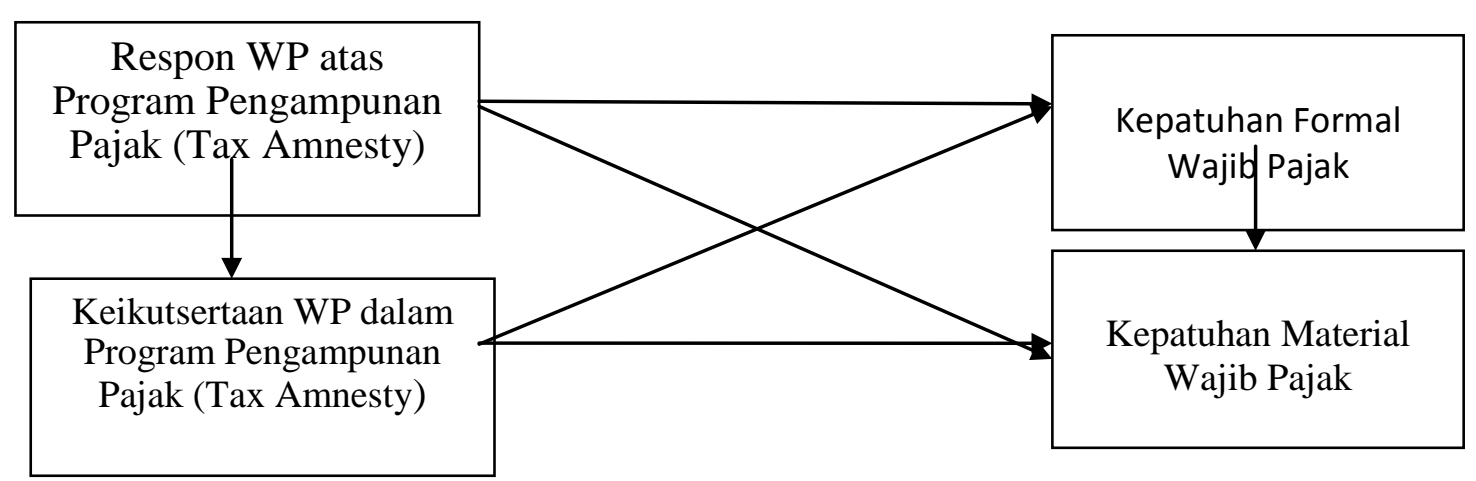

Gambar 1: Kerangka Pemikiran.

\section{METODE PENELITIAN}

Penelitian ini dilaksanakan di wilayah Kantor pelayanan Pajak di Bekasi, yaitu KPP Pratama Bekasi Utara, KPP Pratama Bekasi Selatan, KPP Pratama Cibitung, KPP Pratama Cikarang Utara, KPP Pratama Cikarang Selatan sehingga populasi dalam penelitian ini meliputi seluruh Wajib Pajak di wilayah Kantor Pelayanan Pajak (KPP) Pratama di Bekasi.

Pemilihan teknik pengambilan sampel merupakan upaya penelitian untuk mendapat sampel yang representatif (mewakili), yang dapat menggambarkan populasinya. Menurut Sugiyono (2004) teknik sampling adalah merupakan teknik pengambilan sampel untuk menentukan sampel yang akan digunakan dalam penelitian. Dalam penelitian ini dipakai simple random sampling sebagai dasar pengambilan sampel. Cara atau teknik penarikan sampel ini dipakai karena analisa penelitiannya cenderung deskriptif dan bersifat umum. Perbedaan karakter yang mungkin ada pada setiap unsur atau elemen populasi tidak merupakan hal yang penting. Misalnya dalam populasi ada wanita dan pria, atau ada manajer dan bukan manajer, dan perbedaan-perbedaan lainnya. Perbedaan gender, status kemakmuran, dan kedudukan dalam organisasi, serta perbedaanperbedaan lain tersebut bukan merupakan sesuatu hal yang penting dan mempunyai pengaruh yang signifikan terhadap hasil penelitian

Penelitian ini akan melihat perilaku Wajib Pajak Orang Pribadi (WP OP), untuk itu data yang diambil adalah data WP OP yang terdaftar di KPP di Bekasi, yaitu sebanyak 753.041 Wajib Pajak. Dari jumlah itu akan ditentukan, berapa jumlah sampel yang diperlukan. Dalam penelitian ini penentuan besaran sampel yang memenuhi hitungan adalah yang dirumuskan oleh Slovin sebagai berikut:

Rumus Slovin :

$$
\mathrm{n}=-\frac{\mathrm{N}}{1+\mathrm{N}(\mathrm{e})^{2}}
$$

dimana :

$\mathrm{n} \quad=$ ukuran sampel

$\mathrm{N} \quad=$ ukuran populasi

e $\quad=$ persen kelonggaran ketidaktelitian karena kesalahan pengambilan sampel yang masih dapat ditolerir atau diinginkan. ${ }^{2}$

Untuk menggunakan rumus tersebut, pertama-tama kita harus tetapkan terlebih dahulu taraf keyakinan atau confidence level, misalnya kita tetapkan (...\%) akan kebenaran hasil penelitian (persentase tingkat keyakinan), atau taraf signifikansi toleransi kesalahan $(0, .$.$) terjadi. Dalam$ 
penelitian inidiambil taraf keyakinan 93\%, yaitu yakin bahwa 93\% hasil penelitian benar atau taraf signifikansi 0,07 (akan ada 7\% kesalahan karena kebetulan benar terjadi).

Berdasarkan rumus Slovin, dan dengan persen kelonggaran sebesar 7\%, maka jumlah sampel yang digunakan adalah 204,02 dan dibulatkan menjadi 205 sampel. Jadi jumlah sampel yang digunakan dalam penelitian ini sebanyak 205 responden Wajib Pajak Orang Pribadi (WP OP). Kriteria wajib pajak yang digunakan adalah wajib pajak yang terdaftar dan aktif dalam melakukan kewajiban perpajakan dan memiliki NPWP.

Penelitian ini menggunakan pendekatan metode survey, yaitu merupakan penelitian yang mengambil sampel dari suatu populasi dan menggunakan kuesioner sebagai alat pengumpulan data yang pokok. Pada dasarnya penelitian survey harus memiliki populasi yang telah ditentukan untuk kemudian diambil sampel yang mewakili sebagai objek dari penelitian. Data yang diperlukan diambil dengan menggunakan kuesioner untuk kemudian diolah dengan menggunakan metode yang dipilih. Metode yang digunakan adalah explanatory survey, yaitu menjelaskan hubungan kausal antara variabel-variabel yang ada melalui pengujian hipotesis.

Metode survey ini dilakukan dengan penyebaran kuesioner tertulis untuk menjawab pertanyaan yang ada, yang merupakan metode atau cara yang paling praktis untuk mendapatkan informasi tentang objek yang diteliti. Metode ini dipilih karena akan lebih didapatkan informasi mengenai Kebijakan pengampunan pajak serta pengaruhnya terhadap kepatuhan Wajib Pajak.

Penelitian yang dilakukan adalah penelitian yang bersifat deskriptif dan verifikatif. Penelitian deskriptif adalah penelitian yang betujuan untuk memberikan gambaran atas variabel penelitian. Gambaran yang hendak diperoleh dalam penelitian ini adalah gambaran mengenai variabel kebijakan pengampunan pajak, dan kepatuhan Wajib Pajak.

Penelitian verifikatif adalah penelitian yang bertujuan untuk menguji kebenaran dari suatu hipotesis dengan melakukan pengumpulan data di lapangan. Dalam penelitian ini yang akan diuji adalah pengaruh kebijakan pengampunan pajak terhadap kepatuhan Wajib Pajak.

Teknik pengumpulan data merupakan suatu cara yang digunakan untuk memperoleh data. Adapun teknik pengumpulan data yang digunakan penulis dalam penelitian ini adalah sebagai berikut:

1) Penelitian Lapangan (Field Research)

Melalui penelitian lapangan ini, diharapkan dapat memperoleh data primer, yaitu data yang langsung didapat dari wajib pajak di Bekasi. Teknik pengumpulan data untuk penelitian lapangan ini terdiri dari:

a) Kuesioner dilakukan dengan menyebarkan seperangkat daftar pertanyaan tertulis kepada responden (sampel penelitian). Responden tinggal memilih alternatif jawaban yang telah disediakan dengan membubuhkan tanda (回) pada masingmasing alternatif jawaban yang dianggap paling tepat. Dalam kuesioner ini penulis mengemukakan beberapa pertanyaan yang mencerminkan pengukuran indikator dari variabel independen dan dependen.

b) Wawancara, yaitu diskusi dengan beberapa responden Wajib Pajak untuk melengkapi keterangan yang jelas mengenai tax amnesty dan kepatuhan Wajib Pajak.

2) Penelitian Kepustakaan (Library Research.).

Untuk melengkapi data primer, diperlukan pula data sekunder yang diperoleh dari penelitian kepustakaan. Pengumpulan data sekunder dilakukan dengan mempelajari jurnaljurnal, dan majalah-majalah yang dianggap menunjang pembahasan dan analisis penelitian lapangan.

\section{HASIL PENELITIAN DAN PEMBAHASAN}

Pada bagian ini disajikan gambaran data penelitian yang diperoleh dari hasil jawaban responden, proses pengolahan data, dan analisis hasil pengolahan data tersebut. Hasil 
pengolahan data selanjutnya akan digunakan sebagai dasar untuk analisis dan menjawab hipotesis penelitian yang diajukan. Analisis data yang digunakan adalah Structural Equation Modelling (SEM) dengan terlebih dahulu melakukan pengujian dimensi-dimensinya dengan Confirmatory Factor Analysis.

Pengujian validitas dilakukan dengan melihat nilai standardized loading factor dan nilai $\mathrm{t}$ dari masing-masing yang dihasilkan. Menurut Igbaria et al (1997) nilai t yang dihasilkan harus diatas 1,96. Sedangkan nilai standardized loading factor harus minimal diatas 0,5 ada juga yang mangatakan diatas 0,6. Nilai $\mathrm{t}$ dan nilai standardized loading factor dihasilkan dengan menjalankan program Lisrel melalui jalur path. Sedangkan nilai reliabilitas dapat menggunakan koefisien Cronbach's Alpha dengan menggunakan SPSS. Jika nilai reliabel diatas 0,7 maka dapat dikatakan data tersebut reliable, Malhotra (2007).

Pengukuran variabel wajib pajak dilakukan dengan menggunakan 14 buah pertanyaan. Jawaban terhadap masing-masing item pertanyaan yang berhubungan dengan respon wajib pajak adalah nomor 1 sampai dengan 10. Sedangkan yang berhubungan dengan keikutsertaan Wajib Pajak adalah kuesioner nonor 11 sampai dengan 14. Hasil perhitungan validitas sebagai berikut:

Tabel 1

Respon Wajib Pajak dan keikutsertaanWajib Pajak dalam Program Tax Amnesty Tax amnesty

Pertanyaan R hitung kesimpulan

\begin{tabular}{lll}
\hline P1 & 0,966 & Valid \\
P2 & 0,881 & Valid \\
P3 & 0,920 & Valid \\
P4 & 0,759 & Valid \\
P5 & 0,346 & Tidak Valid \\
P6 & 0,737 & Valid \\
P7 & 0,916 & Valid \\
P8 & 0,990 & Valid \\
P9 & 0,372 & Tidak Valid \\
P10 & 0,961 & Valid \\
P11 & 0,937 & Valid \\
P12 & 0,853 & Valid \\
P13 & 0,876 & Valid \\
P14 & $\underline{0,930}$ & Valid
\end{tabular}

Sumber : Data Primer (diolah 2017)

Dengan demikian pertanyaan yang berhubungan dengan respon Wajib Pajak terdapat 2 pertanyaan yang tidak valid. Sedangkan yang berhubungan dengan Keikutsertaan Wajib Pajak semuanya valid. Pertanyaan yang tidak valid selanjutnya tidak diikutsertakan dalam perhitungan atau dihilangkan.

Hasil perhitungan reliabilitas respon wajib pajak adalah sebagai berikut: 
Tabel 2 Hasil Uji Reliabilitas Kuesioner Respon Wajib Pajak terhadap Program Tax Amnesty

Reliability Statistics

Cronbach's Alpha N of Items

$.937 \quad 10$

Nilai cronbach alpha sebesar 0,937, dimana nilai ini > 0,7. Dengan demikian kuisioner pertanyaan yg berhubungan dengan respon wajib pajak adalah reliabel.

Hasil perhitungan reliabilitas keikutsertaan wajib pajak terhadap program Tax Amnesty sebagai berikut :

Tabel 3 Hasil Uji Reliabilitas Kuesioner atas Respon Wajib Pajak terhadap Program Tax Amnesty

Reliability Statistics

Cronbach's Alpha $\quad$ N of Items

$.960 \quad 4$

Nilai cronbach alpha sebesar 0,960. Nilai ini $>0,7$. Dengan demikian kuisioner pertanyaan yg berhubungan dengan respon Wajib Pajak adalah reliabel.

Pengukuran variabel kepatuhan pajak dilakukan dengan menggunakan 14 pertanyaan.

Tabel 4 Kepatuhan Formal dan Material

\begin{tabular}{|c|c|c|c|}
\hline Kepatuhan Pajak & Pertanyaan & SLF & kesimpulan \\
\hline & P15 & & 0,800 Valid \\
\hline & P16 & & 0,925 Valid \\
\hline & P17 & & 0,395Tidak Valid \\
\hline & P18 & & 0,904 Valid \\
\hline & P19 & & 0,881 Valid \\
\hline & $\mathrm{P} 20$ & & 0,406 Tidak Valid \\
\hline & $\mathrm{P} 21$ & & 0,890 Valid \\
\hline & $\mathrm{P} 22$ & & 0,955 Valid \\
\hline & $\mathrm{P} 23$ & & $\underline{0,845}$ Valid \\
\hline & P24 & & $\overline{0,502}$ Valid \\
\hline & P25 & & 0,955 Valid \\
\hline & P26 & & 0,177Tidak Valid \\
\hline & $\mathrm{P} 27$ & & 0,956 Valid \\
\hline & P28 & & 0,935 Valid \\
\hline
\end{tabular}

Sumber : Data Primer Diolah, 2017

Pertanyaan yang tidak valid dibuang. Dengan demikian peneliti hanya mengambil pertanyaan yang valid

Hasil perhitungan reliabilitas kepatuhan formal adalah sebagai berikut: 
Tabel 5. Perhitungan Reliabilitas Kepatuhan Formal

\title{
Reliability Statistics
}

$$
\text { Cronbach's Alpha N of Items }
$$$$
.905
$$

Nilai cronbach alpha sebesar 0,905 . Nilai ini $>0,7$ dengan demikian kuisioner pertanyaan yg berhubungan dengan kepatuhan formal adalah reliabel.

Hasil perhitungan reliabilitas kepatuhan material sebagai berikut :

Tabel 6. Perhitungan Reliabilitas Kepatuhan Material

\author{
Reliability Statistics \\ Cronbach's Alpha N of Items
}

.895

Nilai cronbach alpha sebesar 0,895. Nilai ini > 0,7 dengan demikian kuisioner pertanyaan yg berhubungan dengan kepatuhan materil adalah reliabel.

Analisis data yang digunakan dalam penelitian ini adalah Structural Equation Model (SEM). Namun demikian beberapa tahapan analisis akan dilakukan untuk membentuk satu model yang terbaik. Input data yang digunakan dalam penelitian ini adalah matrik varians/kovarians. Matriks kovarian dinilai memiliki keuntungan dalam memberikan perbandingan yang valid antar populasi atau sampel yang berbeda, yang kadang tidak memungkinkan jika menggunakan model matriks korelasi.

Model estimasi yang digunakan adalah maximum likelihood estimation. Sebelum pada pengujian model penuh, terlebih dahulu akan dilakukan pengujian secara bertahap yakni estimasi measurement model dengan teknik confirmatory factor analysis.

Analisis hasil pengolahan data pada tahap full model SEM dilakukan dengan melakukan uji kesesuaian dan uji statistik. Hasil pengolahan data untuk analisis full model SEM ditampilkan pada Gambar:

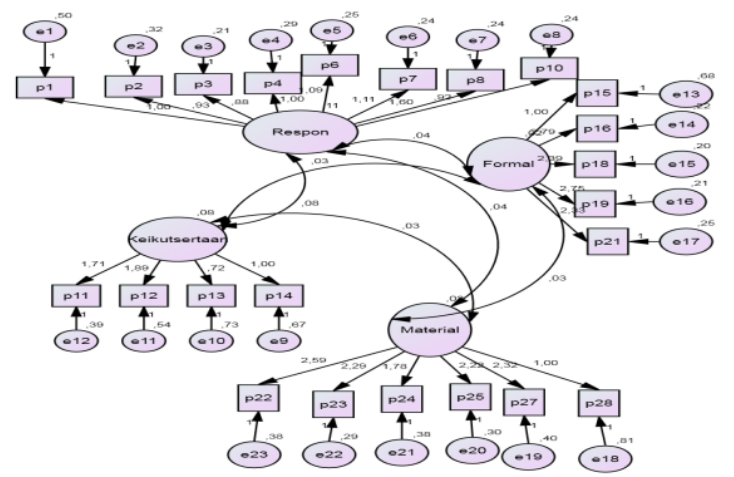

Gambar 2:Hasil Pengujian Full Model Structural Equation Model (SEM) 
Hasil analisis SEM sebagai berikut :

Tabel 7: Hasil Analisis SEM

Correlations: (Group number 1 - Default model)

\begin{tabular}{lllr} 
& & & Estimate \\
\hline Respon & $<->$ & Keikutsertaan &, 873 \\
Respon & $<-->$ & Formal &, 796 \\
Keikutsertaan & $<->$ & Formal &, 703 \\
Respon & $<->$ & Material &, 676 \\
Formal & $<-->$ & Material &, 525 \\
Keikutsertaan & $<-->$ & Material &, 604
\end{tabular}

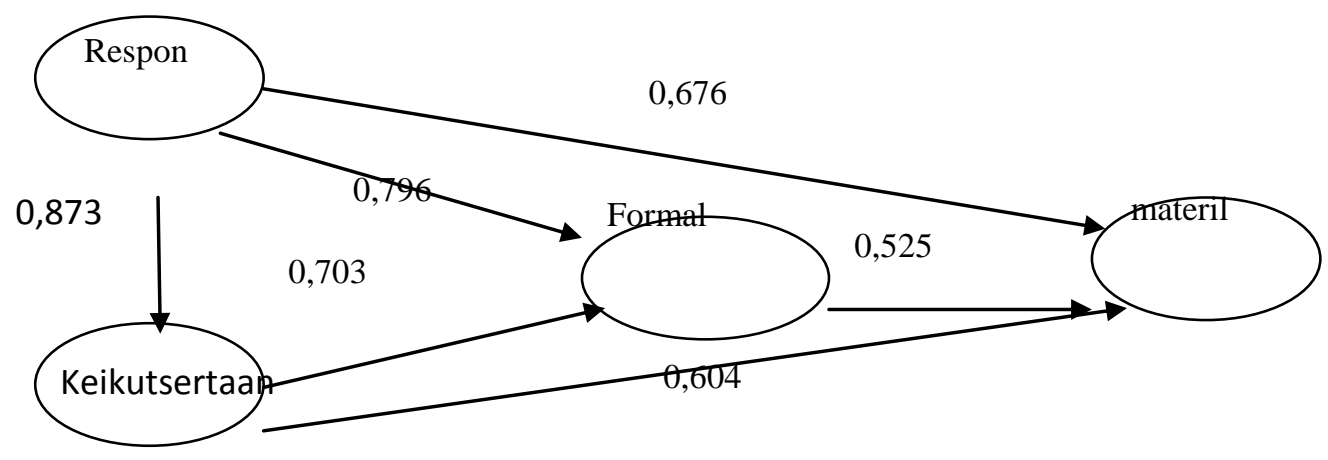

Gambar 3 Uji Hipotesis

Sumber : Data primer yang diolah, 2017

Tabel.8. Interpretasi Nilai Koefisien Korelasi

\begin{tabular}{ccl} 
No. & Nilai $r$ (Nilai Mutlak) & \multicolumn{1}{c}{ Interpretasi Hubungan } \\
\hline 1. & 1 & Kuat dan Sempurna \\
2. & $0,9-<1$ & Sangat kuat \\
3. & $0,8-<0,9$ & Kuat \\
4. & $0,7-<0,8$ & Cukup Kuat \\
5. & $0,6-<0,7$ & Lemah \\
6. & $>0-<0,6$ & Sangat Lemah \\
7. & 0 & Tidak ada Hubungan
\end{tabular}

Sumber : Sugiyono (2000)

\begin{tabular}{lrl} 
Correlations: & $\begin{array}{c}\text { Nilai } \\
\text { Korelasi }\end{array}$ & Ket \\
\hline Respon $---------\rightarrow$ Keikutsertaan & 0,873 & Kuat \\
Respon---------- Formal & 0,796 & Cukup Kuat \\
Keikutsertaan------ $\rightarrow$ Formal & 0,703 & Cukup Kuat \\
Respon-------- $\rightarrow$ Material & 0,676 & Lemah \\
Formal------------- $\rightarrow$ Material & 0,525 & $\begin{array}{l}\text { Sangat } \\
\text { Lemah }\end{array}$ \\
Keikutsertaan------- $\rightarrow$ Material & 0,604 & Lemah
\end{tabular}


Hasil analisis pengolahan data terlihat bahwa konstruk yang digunakan untuk membentuk sebuah model penelitian, pada proses analisis faktor konfirmatori belum sepenuhnya memenuhi kriteria goodness of fit yang telah ditetapkan.

\section{CMIN}

\begin{tabular}{lcc} 
Model & NPAR & CMIN \\
\hline Default model & 52 & 165,036
\end{tabular}

\section{RMR, GFI}

\begin{tabular}{lcccc} 
Model & RMR & GFI & AGFI & PGFI \\
\hline Default model &, 048 &, 921 & &
\end{tabular}

AIC

\begin{tabular}{lrrrr} 
Model & AIC & BCC & BIC & CAIC \\
\hline Default model & 443,036 & 457,299 & 614,548 & 666,548
\end{tabular}

\begin{tabular}{lccc}
$\begin{array}{c}\text { Goodness of Fit } \\
\text { Indeks }\end{array}$ & Cut-off Value & $\begin{array}{c}\text { Hasil } \\
\text { Analisis }\end{array}$ & Evaluasi Model \\
& & & \\
\hline Chi - Square & $\leq 259,518$ & 165,036 & Baik \\
RMSEA & $\leq 0.08$ & 0,048 & Baik \\
GFI & $\geq 0.90$ & 0,921 & Baik
\end{tabular}

Sumber : Data penelitian yang diolah, 2017

Hasil analisis pengolahan data terlihat bahwa semua konstruk yang digunakan untuk membentuk sebuah model penelitian, pada proses analisis full model SEM belum memenuhi kriteria goodness of fit yang telah ditetapkan. Nilai chi square hasil perhitungan lebih kecil dari nilai chi square cut off atau $165,036 \leq 259,518$. Ukuran goodness of fit lain juga menunjukkan pada kondisi yang baik.

1) RMSEA

RMSEA (The root Mean Square Error of Approximation), merupakan ukuran yang mencoba memperbaiki kecenderungan statistik chi square menolak model dengan jumlah sampel yang besar. Nilai RMSEA antara 0.05 sampai 0.08 merupakan ukuran yang dapat diterima. Hasil uji menunjukan nilai RMSEA 0,048 


\section{2) GFI}

GFI (Goodness of Fit Index), dikembangkan oleh Joreskog \& Sorbon, 1984; dalam Ferdinand, 2006 yaitu ukuran non statistik yang nilainya berkisar dari nilai 0 (poor fit) sampai 1.0 (perfect fit). Nilai GFI tinggi menunjukkan fit yang lebih baik dan berapa nilai GFI yang dapat diterima sebagai nilai yang layak belum ada standarnya, tetapi banyak peneliti menganjurkan nilai-nilai diatas $90 \%$ sebagai ukuran Good Fit. Hasil perhitungan menunjukan nilai GFI 0,921.

3) Chi square

Adalah nilai chi square hasil perhitungan adalah $=165$.

Gambaran data hasil tanggapan responden dapat digunakan untuk memperkaya pembahasan, melalui gambaran data tanggapan responden dapat diketahui bagaimana kondisi setiap indikator variabel yang sedang diteliti, yaitu:

1) Analisis deskriptif atas respon Wajib Pajak atas program tax amnesty.Respon Wajib Pajak atas program tax amnesty terungkap melalui jawaban responden terhadap pertanyaanpertanyaan yang diajukan pada kuesioner. yang dioperasionalisasikan menjadi 9 (sembilan) pertanyaan. Berdasarkan hasil penyebaran kuesioner diperoleh gambaran tanggapan responden mengenai respon Wajib Pajak terhadap program tax amnesty, dimana nilai tertinggi adalah pernyataan nomor 8 yang berarti bahwa kebanyakan Wajib Pajak memilih setuju bahwa setelah mengikuti tax amnesty Wajib Pajak menjadi tidak takut melaporkan kewajiban perpajakannya. sedangkan nilai terendah ada pada pertanyaan nomor 6 , yaitu tax amnesty dapat membantu dalam menata memperbaiki kewajiban Wajib Pajak.

2) Analisis Deskriptif atas keikutsertaan Wajib Pajak dalam program tax amnesty.Keikutsertaan Wajib Pajak dalam program tax amnesty terungkap melalui jawaban responden terhadap pertanyaan-pertanyaan yang diajukan pada kuesioner. yang dioperasionalisasikan menjadi 5 (lima) pertanyaan. Berdasarkan hasil penyebaran kuesioner diperoleh gambaran tanggapan responden mengenai keikutsertaan Wajib Pajak dalam program tax amnesty, dimana nilai tertinggi adalah pernyataan nomor 1, bahwa kebanyakan Wajib Pajak memilih setuju bahwa seorang teman bisa mempengaruhi seseorang untuk mengikuti tax amnesty. sedangkan nilai terendah ada pada pertanyaan nomor 4, yaitu apakah konsultan pajak cukup besar mempengaruhi Wajib Pajak untuk mengikuti program tax amnesty. 
3) Analisis Deskriptif atas kepatuhan formal Wajib Pajak Kepatuhan formal Wajib Pajak terungkap melalui jawaban responden terhadap pertanyaan-pertanyaan yang diajukan pada kuesioner. yang dioperasionalisasikan menjadi 7 (tujuh) pertanyaan. Berdasarkan hasil penyebaran kuesioner diperoleh gambaran kapatuhan formal Wajib Pajak, dimana nilai tertinggi adalah pertanyaan nomor 2, yaitu kebijakan tax amnesty dikeluarkan pada saat yang tepat. sedangkan nilai terendah ada pada pertanyaan nomor 1 , yaitu untuk pertanyaan apakah tax amnesty merupakan kebijakan pemerintah yang tepat.

4) Analisis Deskriptif atas kepatuhan material Wajib Pajak Kepatuhan material Wajib Pajak terungkap melalui jawaban responden terhadap pertanyaan-pertanyaan yang diajukan pada kuesioner. yang dioperasionalisasikan menjadi 7 (tujuh) pertanyaan. Berdasarkan hasil penyebaran kuesioner diperoleh gambaran kapatuhan material Wajib Pajak, dimana nilai tertinggi adalah pertanyaan nomor 1 , dimana responden sangat setuju bahwa mereka tidak pernah salah dalam menghitung untuk pengisian SPT.. sedangkan nilai terendah ada pada pertanyaan nomor 5, yaitu untuk pertanyaan apakah kebenaran dalam pengisian SPT merupakan hal yang sangat penting.

5) Hasil perhitungan menunjukan sebagai berikut :

Tabel 9 :Covariances: (Group number 1 - Default model)

\begin{tabular}{|c|c|c|c|c|c|c|c|}
\hline & & & $\begin{array}{r}\text { Estimat } \\
\mathrm{e}\end{array}$ & $\begin{array}{l}\text { S. } \\
\text { E. }\end{array}$ & $\begin{array}{l}\text { C. } \\
\text { R. }\end{array}$ & $P$ & Label \\
\hline Respon & & Keikutsertaan & ,080 &, 025 & $\begin{array}{r}3,19 \\
0\end{array}$ & $\begin{array}{r}, 00 \\
1\end{array}$ & par_20 \\
\hline Respon & $\langle-->$ & Kep. Formal &, 041 &, 020 & $\begin{array}{r}2,08 \\
7\end{array}$ & $\begin{array}{r}, 03 \\
7\end{array}$ & par_21 \\
\hline Keikutsertaan & $\langle-->$ & Kep. Formal & ,030 &, 016 & $\begin{array}{r}1,82 \\
9\end{array}$ & $\begin{array}{r}, 06 \\
7\end{array}$ & par_22 \\
\hline Respon & $<-->$ & Kep. Material & ,037 & ,018 & $\begin{array}{r}2,11 \\
1\end{array}$ & $\begin{array}{r}, 03 \\
5\end{array}$ & par_23 \\
\hline Formal & $<-->$ & Kep. Material & ,026 & ,016 & $\begin{array}{r}1,62 \\
8\end{array}$ & $\begin{array}{r}, 10 \\
4\end{array}$ & par_24 \\
\hline Keikutsertaan & $\langle-->$ & Kep. Material & ,027 &, 014 & $\begin{array}{r}1,91 \\
4\end{array}$ & $\begin{array}{r}, 05 \\
6\end{array}$ & par_25 \\
\hline
\end{tabular}

Uji hipotesis

1) Hubungan antara respon Wajib Pajak atas program tax amnesty terhadap keikutsertaan Wajib Pajak dalam program tax amnesty di Bekasi.

Hasil perhitungan menunjukan angka $p$ sebesar 0,001. Angka ini juga dibawah 0,005 sehingga Ho ditolak. Kesimpulannya terdapat hubungan positif antara Respon Wajib Pajak atas program tax amnesty terhadap keikutsertaan Wajib Pajak dalam program Tax amnesty di Bekasi

2) Hubungan antara respon Wajib Pajak atas program tax amnesty terhadap kepatuhan formal Wajib Pajak di Bekasi

Hasil perhitungan menunjukan angka $p$ sebesar 0,037. Angka ini juga dibawah 
0,005 sehingga Ho ditolak. Kesimpulannya terdapat hubungan positif antara respon Wajib Pajak atas program tax amnesty terhadap Kepatuhan formal Wajib pajak di Bekasi.

3) Hubungan antara keikutsertaan Wajib Pajak atas program tax amnesty terhadap kepatuhan formal Wajib Pajak di Bekasi

Hasil perhitungan menunjukan angka $p$ sebesar 0,067. Angka ini juga diatas 0,005 sehingga Ho diterima. Kesimpulannya tidak terdapat hubungan positif antara keikutsertaan Wajib Pajak atas program tax amnesty terhadap kepatuhan formal Wajib Pajak di Bekasi

4) Hubungan antara respon Wajib Pajak atas program tax amnesty terhadap kepatuhan material Wajib di Bekasi

Hasil perhitungan menunjukan angka $p$ sebesar 0,035. Angka ini juga dibawah 0,005 sehingga Ho ditolak. Kesimpulannya terdapat hubungan positif antara respon Wajib Pajak atas program tax amnesty terhadap kepatuhan material Wajib pajak di Bekasi.

5) Hubungan antara kepatuhan formal Wajib Pajak terhadap kepatuhan material Wajib Pajak di Bekasi

Hasil perhitungan menunjukan angka $p$ sebesar 0,104 . Angka ini juga diatas 0,005 sehingga Ho diterima. Kesimpulannya tidak terdapat hubungan positif antara kepatuhan formal Wajib pajak terhadap kepatuhan material Wajib Pajak di Bekasi

6) Hubungan antara keikutsertaan Wajib Pajak atas program tax amnesty terhadap kepatuhan material Wajib Pajak di Bekasi

Hasil perhitungan menunjukan angka $p$ sebesar 0,056. Angka ini juga diatas 0,005 sehingga Ho diterima. Kesimpulannya tidak terdapat hubungan positif antara keikutsertaan Wajib Pajak terhadap kepatuhan material Wajib Pajak di Bekasi

Indikator bisa tidaknya tax amnesty membantu menata memperbaiki kewajiban Wajib Pajak merupakan indikator dengan skor terendah dalam variabel respon Wajib Pajak atas program tax amnesty. Hal ini artinya masih banyak Wajib Pajak yang belum merasa terbantu oleh kebijakan tax amnesty dalam pelaksanaan kewajiban perpajakannya. Penyebab ini antara lain karena masih banyak Wajib Pajak yang belum memahami arti pentingnya tax amnesty, karena dari tanya jawab yang dilakukan peneliti kebanyakan dari mereka mengikuti tax amnesty karena anjuran dari teman atau lingkungan yang mengatakan sebaiknya mengikuti program tax amnesty agar terbebas dari pemeriksaan pajak sampai dengan tahun 2015 , hanya itu, dimana sesungguhnya mereka belum mengetahui manfaat selanjutnya atas keikutsertaannya.

Indikator ada tidaknya pengaruh atasan sehingga bisa mempengaruhi seseorang untuk mengikuti program tax amnesty merupakan skor terendah dalam variabel keikutsertaan Wajib Pajak atas program tax amnesty. Hal ini berarti peran atasan tidak terlalu besar yang untuk dapat mepegaruhi seseorang mengikuti program tax amnesty. Inilah salah satu contoh, bahwa Wajib pajak tidak begitu tetarik untuk mengikut suatu program kebijakan yang diinformasikan maupun diinstruksikan oleh pimpinannya. Untuk itu kedepannya sebaiknya Ditjen Pejak dalam memberikan sosialisasi atas kebijakan yang akan diambil dapat dilakukan secara menyeluruh kepada Wajib Pajak, jangan hanya berhenti pada pucuk pimpinan di suatu perusahaan. Dengan begitu seluruh Wajib pajak bisa mendengar secara langsung segala manfaat yang akan dirasakan jika mengikuti program tersebut.

Indikator selalu melaporkan jumlah pajak anda yang seharusnya karena merasakan manfaat atas pembayaran pajak merupakan indikator dengan skor terendah dalam variabel kepatuhan Wajib Pajak. Ini merupakan indikasi yang tidak baik, dimana banyak Wajib Pajak yang tidak melaporkan kewajiban pajaknya secara benar. Dengan sistem self assessment yang dianut Indonesia, Wajib Pajak diberi kepercayaan untuk menghitung, membayar dan melaporkan sendiri kewajiban pajaknya. Dengan sistem ini Wajib pajak diharapkan secara bertanggungjawab mau secara sukarela 
melaporkan kewajiban pajaknya secara benar tanpa ada sesuatu yang disembunyikan. namun pada kenyataannya masih banyak Wajib Pajak yang lalai akan hal itu, dimana tidak semua pendapatannya dilaporkan yang mana hal ini akan merugikan pemerintah. Oleh sebab itu perlu dilakukan pendekatan oleh Ditjen pajak yang menghimbau agar Wajib Pajak dapat bersikap jujur. pendekatan itu antara lain bisa dilakukan dengan cara sosialisasi secara berkala, dimana selain memberikan himbauan, juga diberikan gambaran sanksi yang akan dijatuhkan bagi setiap pelanggaran perpajakan. Namun tentunya semua itu disampaikan secara persuasif, karena hanya dengan cara itu para Wajib Pajak akan mendengarkan dan akan memberikan kesadaran akan perlunya bersikap jujur yang pada akhirnya mereka akan menjadi mitra yang baik dengan Ditjen pajak selaku fiskus.

Untuk lebih meningkatkan kepatuhan pajak, diharapkan pemerintah juga memperhatikan faktor lain antara lain dengan meningkatkan intensitas pemeriksaan pajak, dimana Wajib pajak cenderung akan lebih patuh jika telah mengalami pemeriksaan pajak. Faktor lain yang juga perlu diperhatikan adalah masalah sistem perpajakan, dimana sistem perpajakan yang sederhana dan tidak berbelit-belit akan lebih meningkatkan kepatuhan pajak.

Hasil penelitian menunjukan bahwa terdapat hubungan positif antara Respon Wajib Pajak atas program tax amnesty terhadap keikutsertaan Wajib Pajak dalam program Tax amnesty di Bekasi. Hal ini menunjukkan bahwa dengan makin banyaknya respon masyarakat atas program tax amnesty berarti makin besar pula tingkat keinginan untuk mengikuti program tax amnesty.

Hasil penelitian menunjukan bahwa terdapat hubungan positif antara respon Wajib Pajak atas program tax amnesty terhadap Kepatuhan formal Wajib pajak di Bekasi hal ini. Ini artinya semakin tinggi respon Wajib Pajak atas program tax amnesty, maka akan semakin tinggi pula tingkat ketaatan Wajib Pajak dalam rangka pemenuhan kewajiban pajak formalnya.

Hasil penelitian menunjukan bahwa tidak terdapat hubungan positif antara keikutsertaan Wajib Pajak atas program tax amnesty terhadap kepatuhan formal Wajib Pajak di Bekasi hal ini. Artinya bahwa Wajib Pajak yang mengikuti program tax amnesty akan menjadi Wajib pajak yang patuh secara formal. hal ini dimungkinkan karena keikutsertaannya dalam program tax amnesty adalah bertujuan untuk melakukan penghapusan atas sesuatu yang bisa dikatakan sebagai kesalahan ataupun kekeliruan dalam pelaksanaan kewajiban perpajakannnya dimasa lalu. Oleh karenanya kedapannya Wajib Pajak tersebut akan menjadi Wajib Pajak yang patuh secara formal karena upaya awalnya sudah dilakukan dengan mengikuti program tax amnesty tersebut.

Hasil penelitian menunjukan bahwa terdapat hubungan positif antara respon Wajib Pajak atas program tax amnesty terhadap kepatuhan material Wajib pajak di Bekasi. Hal ini menunjukkan bahwa dengan mengikuti program tax amnesty, Wajib pajak selanjutnya berkeinginan menjadi Wajib Pajak patuh secara material. Mereka tentunya akan berfikir sesuatu yang telah dimulai, yaitu dimulai dengan mengikuti program tax amnesty, sebaiknya harus diikuti dengan langkah selanjutnya, yaitu menjadi Wajib Pajak patuh secara material.

Hasil penelitian menunjukan bahwa tidak terdapat hubungan positif antara kepatuhan formal Wajib pajak terhadap kepatuhan material Wajib Pajak di Bekasi. Hal ini menunjukkan bahwa Wajib Pajak yang patuh secara formal, belum tentu menjadi patuh secara material. Dari hasil wawancara peneliti dengan beberapa Wajib Pajak, banyak diantara mereka yang memang sudah menjadi Wajib Pajak patuh secara formal, dimana dia telah menyampaikan laporan SPT, baik untuk Wajib Pajak perorangan maupun Wajib Pajak badan secara tepat waktu tanpa keterlambatan, namun untuk nilai yang dimasukkan banyak yang tidak seseuai dengan kenyataan. Ketidaksesuaian itu bisa disebabkan dari 2 sisi, yang pertama adalah jumlah pendapatan yang dimasukkan tidak 
sebesar yang seharusnya, sedangkan yang kedua adalah besarnya biaya dimasukkan lebih besar dari pada seharusnya, atau bahkan bisa keduanya, pendapatan dimasukkan lebih kecil namun biaya dimasukkan lebih besar.

Hasil penelitian menunjukan bahwa tidak terdapat hubungan positif antara keikutsertaan Wajib Pajak terhadap kepatuhan material Wajib Pajak di Bekasi. Hal ini menunjukkan bahwa Wajib Pajak yang telah mengikuti program tax amnesty tidak serta merta menjadi Wajib Pajak yang patuh secara material. Salah satu alasan mengikuti program tax amnesty antara lain karena mereka menyadari kesalahan ataupun kekeliruan dimasa lalu atas kewajiban perpajakannya dan untuk selanjutnya akan menjadi Wajib pajak patuh, tetapi rupanya kepatuhan tersebut hanya sebatas kepatuhan formal. Mereka belum mampu atau bisa dikatakan belum bisa secara jujur melaporkan kewajiban perpajakannya, karena pastinya akan lebih banyak nilai pembayaran yang pastinya akan keluar.Oleh sebab itu keikutsertaan Wajib Pajak mengikuti program tax amnesty belum diikuti dengan kesadaran untuk menjadi Wajib pajak Patuh secara material.

\section{SIMPULAN DAN SARAN}

Berdasarkan hasil penelitian dan pembahasan yang telah dilakukan mengenai Pengaruh atas Respon dan Keikutsertaan Wajib Pajak dalam Program Tax Amnesty terhadap Kepatuhan Formal dan Material Wajib Pajak di Bekasi, dapat disimpulkan sebagai berikut:

1) Respon Wajib Pajak atas program tax amnesty berpengaruh positif terhadap keikutsertaan Wajib Pajak dalam program tax amnesty di Bekasi

2) Respon Wajib Pajak atas program tax amnesty berpengaruh positif terhadap kepatuhan formal Wajib Pajak di Bekasi

3) Keikutsertaan Wajib Pajak atas program tax amnesty tidak berpengaruh positif terhadap kepatuhan formal Wajib Pajak di Bekasi

4) Respon Wajib Pajak atas program tax amnesty berpengaruh positif terhadap kepatuhan material Wajib di Bekasi

5) Kepatuhan formal Wajib Pajak tidak berpengaruh terhadap kepatuhan material Wajib Pajak di Bekasi

6) Keikutsertaan Wajib Pajak atas program tax amnesty tidak berpengaruh terhadap kepatuhan material Wajib Pajak di Bekasi

Berdasarkan hasil penelitian yang telah dibahas dan disimpulkan, disampaikan saran serta implikasi hasil penelitian sebagai berikut:

1) Indikator bisa tidaknya tax amnesty membantu menata memperbaiki kewajiban Wajib Pajak merupakan indikator dengan skor terendah dalam variabel respon Wajib Pajak atas program tax amnesty. Untuk itu agar Direktorat Jenderal Pajak untuk selalu memberikan sosialisasi tentang tax amnesty dan kebijakan-kebijakan lainnya, sehingga masyarakat yang ikut serta dalam suatu program tertentu menjadi jelas, yang pada akhirnya akan terpuaskan bahwa apa yang mereka lakukan akan memberikan manfaat kedepannya.

2) Indikator ada tidaknya pengaruh atasan sehingga bisa mempengaruhi seseorang untuk mengikuti program tax amnesty merupakan skor terendah dalam variabel keikutsertaan Wajib Pajak atas program tax amnesty. Untuk itu sebaiknya Ditjen Pejak dalam memberikan sosialisasi atas kebijakan yang akan diambil dapat dilakukan secara menyeluruh kepada Wajib Pajak, jangan hanya berhenti pada pucuk pimpinan di suatu perusahaan. Dengan begitu seluruh Wajib pajak bisa mendengar secara langsung segala manfaat yang akan dirasakan jika mengikuti program tersebut. 
3) Indikator selalu melaporkan jumlah pajak anda yang seharusnya karena merasakan manfaat atas pembayaran pajak merupakan indikator dengan skor terendah dalam variabel kepatuhan Wajib Pajak. Oleh sebab itu perlu dilakukan pendekatan oleh Ditjen pajak yang menghimbau agar Wajib Pajak dapat bersikap jujur. pendekatan itu antara lain bisa dilakukan dengan cara sosialisasi secara berkala, dimana selain memberikan himbauan, juga diberikan gambaran sanksi yang akan dijatuhkan bagi setiap pelanggaran perpajakan.

4) Untuk lebih meningkatkan kepatuhan pajak, diharapkan pemerintah juga memperhatikan faktor lain antara lain dengan meningkatkan intensitas pemeriksaan pajak, dimana Wajib pajak cenderung akan lebih patuh jika telah mengalami pemeriksaan pajak. Faktor lain yang juga perlu diperhatikan adalah masalah sistem perpajakan, dimana sistem perpajakan yang sederhana dan tidak berbelit-belit akan lebih meningkatkan kepatuhan pajak.

5) Kepada peneliti-peneliti selanjutnya, diharapkan dapat dilakukan penelitian lanjutan dengan menambahkan variabel-variabel lain yang yang akan dapat mempengaruhi tingkat kepatuhan pajak.

\section{DAFTAR PUSTAKA}

Ali, M.M Cecil, M., Cecil, H.W. \& Knoblett, J.AWayne, 2001. The Effect of Tax and Enforcement Policies on Taxpayer Compliance: A Study of Self-Employed Taxpayers. Atlantic Economic Journal, 29,2; Abi/Inform pg.186.

Allingham, M.G. \& Sandmo, A. 1972. Income Tax Evasion : A Theoretical Analysis. Journal of Public Economics, 1, 323-338, 1972.

Driessche, F.V. Creating Taxpayer Awarness: Corporate Social Responsibility and The Forums for Taxpayer- Tax Administration Dialogue. Case Study Topic 2.3, European Commission.

Elliott, J. E. John E .P., \& Farideh M..2001. Adam Smith's Mode of Social Organization. International Journal of Social Economics. 28.5-7 (2001): 591-599.

Field, L.P \& Frey, B.S. 2002. Trust breeds trust: How taxpayers are treated. Economics of Governance. $3: 87-99$.

Imam Ghozali. 2005. Aplikasi Analisis Multivariate dengan Program SPSS. Semarang: Universitas Diponegoro.

Lai M.L, Zalilawati,Y. Amran, M.M \& Choong, K.F.2013. Tax Education in Non-Accounting Curriculum: A Malaysian Study. Asian Social Science.

Miando Sahala H. Panggabean. 2002. Self Assessment, Fiskus dan Kepatuhan Wajib Pajak. Berita Pajak, No. 1462/Tahun XXXIV, p. 31 - 33.

Nar, Mehmet, 2015. The Effects of Behavioral Economics on Tax Amnesty, International Journal of Economics and Financial Issues, 2015, 5(2), 580-589.

Nirawan Adiasa. 2013. Pengaruh Pemahaman peraturan Pajak Terhadap Kepatuhan Wajib Pajak dengan Moderating Preferensi Risiko. Accounting Analysis Journal.

Palil, M.R. 2010. Tax Konwledge and Tax Compliance Determinants in Self Assessment System 
in Malaysia. Thesis. Birmingham

Palil, M.R. 2005. Taxpayers Knowledge: A Descriptive Evidence on Demographic Factors in Malaysia. Jurnal Akuntansi dan Keuangan. Vol. 7, No.. 1, Mei 2005: 11- 21

Riahi Belkaoui, Ahmed. 2004. Relationship Between Tax Compliance Internationally and Selected Determinants of Tax Morale. Working Paper, University of Illinois at Chicago.

Safri Nurmantu. 2007. Budaya organisasi: dari chester I Barnard ke Michael E. Porter. Penerbitan : Midada Rahma Press.

Sandmo, A. 2004. The Theory of Tax Evasion: A Retrospective View. Journal of Public Economics

Sekaran, U, Research Methods for Business: A Skill Building Approach, ed. 4, New York: John Wiley \& Sons.

Singgih Riphat, S. 2013. Tanggapan Terhadap Makalah Insentif Fiskal dalam Upaya meningkatkan Daya Saing industri Nasional dan Industri Berwawasan Lingkungan.

Siti Resmi. 2009. Perpajakan: Teori dan Kasus. Edisi kelima. Jakarta : Salemba Empat.

Smith, Adam. (1976). An Inquiry into the Nature and Causes of the Wealth of Nations, University of Chicago Press, Chicago, EL (1776).

Valerie Braithwaite, Monika Reinhart and Michael Smart1: Tax non-compliance among the under-30s Knowledge, obligation, or skepticism?

Tower, Ralph B. 2015. Tax Amnesty: Forgiveness in an Unforgiving Word.

Widi Widodo. 2010. Moralitas, Budaya dan Kepatuhan Pajak. Bandung: Alfabeta.

Widi Widodo \& Djefris, D. 2008. Tax Payer's Rights, Apa Yang Perlu Kita Ketahui tentang Hak-hak Wajib Pajak. Bandung: Alfabeta. 